\title{
The Development of Arcs-Based Economics E-Book for Grade 11 of Senior High School
}

\author{
Kartika Yunita Saputri ${ }^{1}$, Sigit Santoso ${ }^{2}$, Aniek Hindrayani ${ }^{3}$ \\ \{kartikayunitas@student.uns.ac.id ${ }^{1}$, sigitsantosa@staff.uns.ac.id ${ }^{2}$, aniek@ staff.uns.ac.id $\left.^{3}\right\}$
}

Sebelas Maret University, Surakarta, Indonesia

\begin{abstract}
This study aimed to investigate the appropriateness of an ARCS-based economics e-book on international trade topics specifically developed for grade 11 (social study program) high school students. The focus was on the experts' assessments and students' responses to the e-book. This study adapted Borg and Gall's learning media development model into 10 stages: (1) research and information collection, (2) planning, (3) developing preliminary e-book form product, (4) preliminary trials, (5) first revision, (6) main trial, (7) second revision, (8) operational trial, (9) third revision, and (10) dissemination of research. The researchers obtained the data using validation and questionnaire sheets and then analyzed the data descriptively. The results showed that the expert team rated the ARCS-based economics e-book's appropriateness as very high. The media expert gave an average score of $93.75 \%$, the content expert gave $88.09 \%$, and the linguist gave $100 \%$. Moreover, students also gave positive responses with an average score of 76,11\%). It can be concluded that the development of an ARCS-based economic ebook for class XI SMA is appropriate for use in the learning process.
\end{abstract}

Keywords: e-book, economics, ARCS, development, student.

\section{Introduction}

The rapidly developing science and technology shape all aspects of life, including education. Developments in education stimulate various innovations which incorporate technology in learning activities. The global generation becomes increasingly aware of the technology to expand knowledge [1]. This is a great potential that teachers should maximize to carry out the learning process effectively. Learning is an activity that constitutes communication between teachers and students. The ongoing learning process has encountered several obstacles. One should utilize appropriate learning media to overcome obstacles.

Learning media resources obtained from the development of technology in learning activity [2], is one of the supporting components to achieve the learning goal. Using learning media helps teachers deliver material easily and increases students' learning motivation and mastery of subjects taught. Teachers mostly used textbooks, modules, and PowerPoint slides as learning media. These media have a common limitation, that is these media are less practical to use. The learning media limitation opens opportunities for the use of technology in learning activities.

Digital technology develops rapidly as in mobile phone or smartphone case. Humans' needs for instantaneous and fast communication and problem solution drove the emergence of smartphones. Over time, the smartphone designs become increasingly sophisticated and it slowly replaces computers and laptops commonly used for work. Smartphone is a helping powerful tool to support humans' work. Nowadays, most people have a smartphone. 
Indonesia has the third-largest smartphone users in Asia Pacific with 83.18 million users in 2018. The development of smartphone in Indonesia was phenomenal, especially in the last five years. Not only adults but also adolescents use smartphones. Users use smartphone as learning, entertainment, communication, and business tools. In education sector, for example, many smartphone applications have been created specifically for students and learning purposes.

Students use smartphones only to access social media [3]. However, the use of smartphone is not only limited to social media networking. It has a positive impact in accelerating the process of finding information in learning activities. Students can easily find the information they need using smartphone. However, students' use of smartphone also brings negative impacts including game addiction, unknown connections via social media, and access to inappropriate content in the internet.

Using smartphone as a learning media can reduce the negative effects of using smartphones on students. Learning media plays an important role in the learning process; it acts as a source of independent learning for students and a means to facilitate learning for teachers [4]. The use of smartphone as a learning media can be seen for example in digital books or e-book (electronic book). E-book is a digital textbook containing text, images, and videos, which can be read on electronic devices [5]-[6]. Text, images, and videos can enhance the impression e-book. E-book is the latest technological breakthrough which will replace printed books in the prospective and advanced future [7].

An e-book has several benefits, including (1) it is easy to use anytime and anywhere; (2) the digital file is durable and difficult to rot; (3) it is possible to preserve a larger number of book references; (4) it can increase readers' learning satisfaction [8]-[9]. Students recognize the benefits of e- book and e-book is recommended in a learning environment [10]. The development of e-book is inseparable from its use e-book as a learning media.

Senior high school in Indonesia (hence abbreviated as SMA) is grades 10-12 of formal secondary school which aimed at producing educated graduates and preparing students to pursue higher education. There are eight public SMA (SMA negeri) and 20 private SMA (SMA swasta) in Surakarta. Of these schools, private SMA Al Azhar Budi Syifa Surakarta is formal secondary schools in Surakarta noted for their academic and non-academic achievements in natural science (IPA) and social sciences (IPS) programs. Indonesian senior high schools offer economics lessons, which in part discuss the basics of economics. For examples, one of the topics discussed in grade 11 economics lesson for IPS program is international trade. To successfully master the lesson and complete the assignment, students must understand some international trade theories.

The economics teacher interviewees suggested that they still utilized printed books from libraries that students borrow to study economics lesson. The printed book is not easy to carry anywhere, and the content is difficult to understand. This situation decreases students' learning motivation, which may lead to lower learning outcomes. It contradicts the learning objectives comprising students' high learning motivation and good learning outcomes. Since the learning processes in both schools allow students to use smartphones, the researchers wanted to make a breakthrough by developing a smartphone-mediated learning media in the form of an e-book.

The process of developing e-book as learning media can be integrated with learning models, such as Attention, Relevance, Confidence, and Satisfaction (ARCS) learning model. ARCS model is an approach to problem solving in learning that is designed using a motivational component and is directed to provide encouragement to students [11]. Students can build preliminary knowledge to understand new material used to solve a 
problem in the learning process using ARCS model [12]. The ARCS model can improve students' learning motivation and learning outcomes [13]. The ARCS-based e-book can increase students' attention and improve their self-confidence in learning [14].

Some previous studies seemed to confirm the findings. Mawaddah investigated students' LKS and found that the development of students' worksheets (LKS) with the ARCS strategy can improve their learning outcomes [15]. Similarly, Suwartini and Fujiastuti revealed that the creation of ARCS-based textbooks can improve students' critical and creative thinking skills [16]. Lastly, Fadilah et al. found that the use of ARCS-based modules can motivate students to learn independently and easily understand the material taught [17].

These literature and previous studies have showed that the ARCS model can increase students' participation, motivation, and learning outcomes. Therefore, the researchers is interested to investigate whether the use of an ARCS-based economics e- book in teaching and learning processes. The question is how to develop an ARCS-based economics e-book that is suitable for learning process.

\section{Research Method}

This research was a development research aimed to produce an ARCS-based economics e-book that is ready for use in the learning process. Sugiyono's model of developmental study design, which based on Borg and Gall's model was adapted in the current study. Sugiyono proposed 10 stages, namely (1) research and information collection, (2) planning, (3) developing preliminary e-book form product, (4) preliminary trials, (5) first revision, (6) main trial, (7) second revision, (8) operational trial, (9) third revision, and (10) dissemination of research [18]. The current study was conducted from May to August 2020. The subjects of the study were grade 11 (senior high school) students in Surakarta. The samples were taken from private high school SMA Al Azhar Budi Syifa Surakarta.

In the preliminary stage, the researchers conducted a literature study to find supporting theories and a field study by means of student interview and questionnaire to collect in-depth information as the basis for the main research. In this stage, the researchers distributed questionnaires and interviewed students to obtain valid data. The data collection techniques used in the main study included observation, interview, questionnaire on learning media development, expert validation, and documentation.

The researchers employed quantitative and qualitative analyses. The interview, observation, and documentation data were examined using qualitative descriptive analysis. The other data, including expert team validation and questionnaire data were analyzed using quantitative descriptive analysis. The researchers employed an experimental design for the effectiveness test, namely the pre-test, post-test, and control group designs. The collected data were processed using SPSS software.

\section{Result and Discussion}

\subsection{Preliminary study}

The preliminary observation of the learning process at three senior high schools in Surakarta, (SMA Al Azhar Budi Syifa Surakarta, SMA Negeri 5 Surakarta, and SMA Negeri 3 Surakarta), showed three main findings. First, teachers had problems in using learning media 
based on learning models; (2) teachers had difficulty in allocating time during the learning process; (3) teachers had not applied an appropriate learning model to enhance students' learning motivation; (4) the learning media used did not include e-books based on the learning model in school; and (5) teachers tended to use library textbooks and student worksheets (LKS) to deliver subjects. The preliminary teacher interviews suggested that it is necessary to create an economics e-book based on the ARCS model to facilitate economics learning.

An e-book was created under the school curriculum and the ARCS (Attention, Relevance, Confidence, Satisfaction) learning model. The e-book cover, the material content, and the display are made as attractive as possible. Every introduction of chapter contains motivational reading to encourage students to learn and adjust with the basic competence, for example, international trade.

The e-book draft was developed following the ARCS learning model to make it easier for teachers and students to use. Afterwards, an expert team authenticated the e- book draft. Next, the researchers conducted a trial study to assess the appropriateness of the ARCS-based economics e-book and gain inputs and suggestions on the economics e- book. After several rounds of validations and trials, the ARCS-based economics e-book for grade 11 students was ready to use by .

The expert team's validations were aimed to assess the feasibility of ARCS-based economics e-book product. The expert team comprised media experts, content experts, and linguists. The expert team's suggestions were used as references to improve and enhance the ARCS-based economics e-book.

\subsection{Media expert validation}

The researchers undertook the media validation by distributing a questionnaire to members of the expert team. The media aspects measured were the visual and the technical aspects of e-book. The assessment results is displayed in Table 1.

Table 1. Results of media experts' validation

\begin{tabular}{ccccccc}
\hline \multirow{2}{*}{ No } & Aspect of Media & \multicolumn{5}{c}{ Scoring Scale } \\
\cline { 3 - 7 } & Assessment & $\mathbf{\Sigma} \boldsymbol{n i}$ & $\mathbf{\Sigma}$ & $\mathbf{1 0 0 \%}$ & Score & Criteria \\
\hline \multirow{2}{*}{1} & Display & 44 & 48 & $100 \%$ & $91.87 \%$ & Very Good \\
2 & Technical & 31 & 32 & $100 \%$ & $96.87 \%$ & Very Good \\
\hline & Total Score & 75 & 80 & $100 \%$ & $93.75 \%$ & Very Good \\
\hline
\end{tabular}

Table 1 shows that media experts rated the ARCS-based economics e-book as a learning media very high $(93.75 \%)$. The display aspect scores high $(91.67 \%)$, so does the technical aspect $(96.87 \%)$. The results show that the ARCS-based economics e-book has met the requirements of a learning media and is suitable media to support economics learning process. Students recognize the benefits of e-book and e-book is recommended in a learning environment [10].

\subsection{Content Expert Validation}

Content validation was carried out by distributing a questionnaire to the expert team. Table 2 displays the results of content validation.

Table 2. Results of content expert validation. 


\begin{tabular}{ccccccc}
\hline \multirow{2}{*}{ No } & \multirow{2}{*}{ Aspect of Media Assessment } & \multicolumn{5}{c}{ Scoring Scale } \\
\cline { 3 - 7 } & & $\mathbf{\Sigma} \boldsymbol{n i}$ & $\boldsymbol{\Sigma} \boldsymbol{N}$ & $\mathbf{1 0 0 \%}$ & Score & Criteria \\
\hline 1 & Appropriateness of Content & 42 & 44 & $100 \%$ & $95.45 \%$ & Very Good \\
2 & Appropriateness of presentation & 34 & 40 & $100 \%$ & $85.00 \%$ & Very Good \\
\hline \multicolumn{2}{c}{ Total Score } & 76 & 84 & $100 \%$ & $88.09 \%$ & Very Good \\
\hline
\end{tabular}

The content expert validation of the appropriateness of ARCS-based economics e-book showed that the content expert evaluated the appropriateness of content and presentation highly, respectively $95.45 \%$ and $85 \%$ (very good criteria). The average score is $88.09 \%$ (very good criteria). Thus, it can be concluded that the ARCS-based economics e-book is suitable for grade 11 students' economics learning.

\subsection{Linguist Validation}

Language aspects validated include conformity with the development of students' thinking skill, readability, ability to motivate students, straightforwardness, coherence and sequence of thought, and conformity with language rules. The results of the linguist's validation is shown in Table 3.

Table 3. Results of linguist's validation.

\begin{tabular}{clccccc}
\hline \multirow{2}{*}{ No } & \multicolumn{1}{c}{ Aspect of Media Assessment } & \multicolumn{5}{c}{ Scoring Scale } \\
\cline { 2 - 6 } & $\mathbf{\Sigma} \boldsymbol{n i}$ & $\boldsymbol{\Sigma} \boldsymbol{N}$ & $\mathbf{1 0 0 \%}$ & Score & Criteria \\
\hline 1 & $\begin{array}{l}\text { Conformity with the development of } \\
\text { students' thinking skill }\end{array}$ & 8 & 8 & $100 \%$ & $100 \%$ & $\begin{array}{c}\text { Very } \\
\text { Good }\end{array}$ \\
2 & $\begin{array}{l}\text { Readability } \\
3\end{array}$ & 4 & 4 & $100 \%$ & $100 \%$ & $\begin{array}{c}\text { Very } \\
\text { Good }\end{array}$ \\
4 & Ability to motivate & 8 & 8 & $100 \%$ & $100 \%$ & $\begin{array}{c}\text { Very } \\
\text { Good }\end{array}$ \\
5 & Straightforwardness & 8 & 8 & $100 \%$ & $100 \%$ & $\begin{array}{c}\text { Very } \\
\text { Good } \\
\text { Coherence and sequence of thought }\end{array}$ \\
6 & Conformity with language rules & 8 & 8 & $100 \%$ & $100 \%$ & $\begin{array}{c}\text { Good } \\
\text { Very } \\
\text { Good }\end{array}$ \\
\hline & Total Score & 4 & 4 & $100 \%$ & $100 \%$ & $\begin{array}{c}\text { Very } \\
\text { Good }\end{array}$ \\
\hline
\end{tabular}

Table 3 shows that the use of language in the ARCS-based economics e-book obtains an excellent linguist validation (100\%). The results indicate that the economics e- book is remarkable and thus suitable for use as a learning media.

Table 4. Validation team's advice.

\begin{tabular}{ll}
\hline \multicolumn{1}{c}{ Feedback } & \multicolumn{1}{c}{ Response } \\
\hline Media Expert & Conducting another limited trial study \\
\hline The media can be used for future research & \\
\hline Content Expert & $\begin{array}{l}\text { Refining the content according to the } \\
\text { curriculum, ARCS model, and students' needs }\end{array}$ \\
\hline The content needs to be further refined & \\
\hline Linguist & \\
\hline
\end{tabular}


Typos should be double-checked

Typos are corrected according to linguist's advice

Table 4 shows media, content, and language experts' advice and the researchers' response. The researchers revised the e-book accordingly. The process was in line with Istifarida et al. who had developed an e-book which they found suitable for their students' learning [19].

\subsection{Limited trial study}

A limited trial was conducted to obtain student responses' on the ARCS-based economics e-book. Nine grade 11 students of SMA Al Azhar Syifa Budi Surakarta were recruited. The results of the trial study is shown in Table 5.

Table 5. Results of the limited trial study.

\begin{tabular}{ccccccc}
\hline \multirow{2}{*}{ No } & \multirow{2}{*}{ Aspect of Media Assessment } & \multicolumn{5}{c}{ Scoring Scale } \\
\cline { 3 - 6 } & \multirow{2}{*}{$\boldsymbol{n i}$} & $\boldsymbol{\Sigma} \boldsymbol{N}$ & $\mathbf{1 0 0 \%}$ & Score & Criteria \\
\hline 1 & Presentation & 141 & 180 & $100 \%$ & $78.33 \%$ & Good \\
2 & Technical Quality & 140 & 180 & $100 \%$ & $77.78 \%$ & Good \\
3 & Benefits & 130 & 180 & $100 \%$ & $72.22 \%$ & Good \\
\hline \multicolumn{2}{c}{ Total Score } & 411 & 540 & $100 \%$ & $76.11 \%$ & Good \\
\hline
\end{tabular}

The results of the trial study ( $\mathrm{n}=9$ students) showed that an overall mean score of $76.11 \%$ (good criteria). Students gave positive responses to the ARCS-based economics e-book. It can be concluded from the study that the e-book is suitable for use as an economic learning media and thus it can be applied to broader audiences.

\section{Conclusion}

The current study which employed expert team validation, supported by a limited trial study on students' perception $(n=9)$, found that the ARCS-based economics e-book developed were suitable for use in economics classes. Using ARCS-based economics e- book could enhance students' learning motivation, stimulate students to learn independently, and improve students' learning outcomes.

\section{Suggestion}

Teachers should be able to develop learning media based on the learning model prescribed by the curriculum and students' situation. Teachers can improve the developed e-book and add materials according to the basic competency required. The use of ARCS- based economics ebook can assist students to understand the material taught better. The e-book is also expected to motivate students to search for other learning references actively because the ARCS model emphasizes students' learning motivation. In addition, the school principal should motivate and support teachers by organizing trainings to develop learning media based on students' needs. Lastly, future researchers should develop more innovative, creative, and communicative e-book. 


\section{References}

[1] Dwiningsih, K., Sukarmin, Nf., Muchlis, Nf., \& Rahma, P.T. 2018. Pengembangan Media Pembelajaran Kimia Menggunakan Media Laboratorium Virtual Berdasarkan Paradigma Pembelajaran di Era Global. Kwangsan: Jurnal Teknologi Pendidikan, 6(2), 156- 176.

[2] Warsita, B. 2017. Peran dan Tantangan Profesi Pengembang Teknologi Pembelajaran pada Pembelajaran Abad 21. Kwangsan: Jurnal Teknologi Pendidikan, 5(2), 77- 90.

[3] Wulandari, N. K. M., Darmawiguna, I. G. M., \& Wahyuni, D. S. 2014. Survey Deskriptif Optimalisasi Penggunaan Smartphone di Kalangan Mahasiswa dan Siswa Se Kota Singaraja, Karmapati, 3(6), 401-410.

[4] Rusman, 2012. Model-model Pembelajaran: Mengembangkan Profesionalisme Guru. Jakarta: PT. Rajagrafindo Persada.

[5] Chen, H. Y., \& Jang, S. J. 2013. Exploring the Reasons for Using Electric Books and Technologic Pedagogical and Content Knowledge of Taiwanese Elementary Mathematics and Science Teachers. The Turkish Online Journal of educational Technology, 12(2), 131-141.

[6] Liaw, S.s., \& Huang, H. M. 2014. Investigating Learner Attitudes Toward E-Books as Learning Tools: Based on The Activity Theory Approach. Interactive Learning Environments, 1-19

[7] Casselden. B., \& Pears, R. 2019. Higher education student pathways to ebook usage and engagement, and understanding: Highways and cul de sacs. Journal of Liberianship and Information Science, 19.

[8] Nguyen, N. 2015. Designing and Using Interactive E-Books in Vietnam. International Journal of Learning, Teaching and Educational Research, 11 (1), 75-98.

[9] Tuah, Herman, N. D., Maknun. J. 2019. E-Book in Teaching and Learning Process. Advance in Social Science, Education and Humanies Research, 299, 281-287.

[10] Kissinger, J. S. (2013). The Social and Mobile Learning Experiences of Students Using Mobile, Journal of Asynchronous Learning Networks, 17, 1, 155-169.

[11] Keller, J.M. 1983. Development and use of the ARCS model of motivational design. East Lansing, MI: National Center for Research on Teacher Learning.

[12] Reynolds, K. M., Roberts, L. M., \& Hauck, J. 2017. Exploring motivation: integrating the ARCS model with instruction. Reference Services Review, 45 (2), 149-165.

[13] Li, K., \& Keller, J. M. 2018. Use of the ARCS model in education: A literature review. Computers \& Education, 122, 54-62.

[14] Turel, Y.K., \& Sanal, S.O. 2018. The Effects of an ARCS based E-book on Student's Achievement, Motivation and Anxiety. Computers \& Education, 127, 130-140.

[15] Mawwadah, M. 2015. Pengembangan LKS dengan Strategi Motivasi ARCS di SMA (Materi Sistem Koordinasi). e-journal.unesa.boiedu, 4(2), 889-896. ISSN: 2302- 9528.

[16] Suwartini, I., \& Fujiastuti, A. 2017. Teknik Pembuatan Buku Ajar Membaca Kritis dan Kreatif Berbasis ARCS untuk Mahasiswa Pendidikan Bahasa dan Sastra Indonesia. Bahastra, 7(2), 138-147.

[17] Fadilah, R. N., Yahya, F., \& Rahman, A. H. 2016. Pengembangan Modul Fisika Berorientasi pada Model Motivasi ARCS Pokok Bahasan Suhu dan Kalor Siswa Kelas X SMA. Prosiding Seminar Nasional Pendidikan 2016, 366-376. ISBN: 978-602-61182-0-2.

[18] Sugiyono. 2015. Metode Penelitian Kombinasi (Mix Methods). Bandung: Alfabeta.

[19] Istifarida, B., Santoso, S., \& Yusup, Y. 2017. Pengembangan E-Book Berbasis Problem Based Learning GIS untuk Meningkatkan Kecakapan Berpikir Keuangan pada Siswa Kelas X. 